\title{
Analysis of Textbooks for Teaching Arabic as a Foreign Language in terms of the Cultural Curriculum
}

\author{
Magdalena Lewicka*, Anna Waszau \\ Department of Arabic Culture and Language, Nicolas Copernicus University, Poland
}

Copyright $\bigcirc 2017$ by authors, all rights reserved. Authors agree that this article remains permanently open access under the terms of the Creative Commons Attribution License 4.0 International License

\begin{abstract}
The subject of this paper is embedded in the context of the issues of cultural and religious studies on the grounds of the contemporary glottodidactics, since it contains the characteristics of the selected textbooks for learning Arabic as a foreign language in the aspect of the content of the cultural thematic corpus. Three various textbooks, representing three various publishing markets (Poland, France, United States of America) have been analyzed to assess the extent of the presence of the cultural and regional knowledge elements. This analysis allowed answering the question regarding the method of reflecting the aspects forming the socio-cultural competence of a student and the extent of such reflection.
\end{abstract}

Keywords Glottodidactics, Teaching Arabic, Cultural Competence, Intercultural Communication

\section{Introduction}

The idea of combining the practice of teaching foreign languages with the presentation of the realities and culture has been postulated by European glottodidactics for many years. This notion is reflected in the formation of a new glottodidactic discipline known as intercultural glottopedagogy and in the formulation of such set terms as: die Landeskunde (German), area studies (English), la civilisation (French), la civiltà (Italian) or stranovedenie (Russian). Lack of a similar term referring to the didactics of Arabic and the aspect of making students familiar with the culture of the Arabic language area does not mean that teaching this language should not be strongly embedded in the cultural context. The skill of efficient communication is the key didactic objective of teaching a language using the dominating communicative approach. However, the fact that the efficiency of the communication in a given language can be threatened by the lack of the so called intercultural competence is not disputable. The intercultural competence is defined as the ability to communicate with the representatives of the various cultural circles and nations and the skills of building the "bridges of communication". In other words, it is a complex skill of managing oneself in the complicated reality of the multilingual and multicultural modern world.

The appropriate place of the cultural aspects accompanying the linguistic behaviour and included in the linguistic maintenance of the culturally determined concepts, is an essential element of the communicative competence on each level of learning. A language does not only play the role of an information channel in the communication process, but also each type of behaviour in a specific communication. Failure to include the cultural and realities-studies elements (or elements conditioned by them) in the course of learning a language may contribute to hindering the communication and adaptation of the new cultural codes, or even lead to the "cultural shock" suffered by a learner. Hence, gradual introduction of the lexical material marked with culture is necessary from the very first level. Such material will allow the improvement of the language skills and knowledge of the culture with its specific elements approximating the world of the values, mentality and stereotypes functioning in a given cultural circle or a nation.

\section{Polish Textbooks for Teaching Arabic}

Infinitesimal popularity of Arabic, in comparison with other European (English, Spanish, Italian, to name but a few) and eastern (Chinese and Japanese) languages, implicates the fact that the number of publications dedicated to teaching Arabic available on Polish market is quite low.

Apart from university textbooks designed to cater for the needs of the courses on the practical learning of the language within the scope of such academic courses as Arabic studies (Jagiellonian University, University of Warsaw, Adam Mickiewicz University in Poznań); applied linguistics English with Arabic (Kazimierz Wielki University in Bydgoszcz) and French with Arabic (Nicolas Copernicus University in Toruń), one can find only a limited number of textbooks or course books.

The best known publication is Jezzy arabski. Teksty $i$ 
ćwiczenia [Arabic. Texts and exercises] by Adnan Abbas and Amira Abbas [1] which shall be analyzed in the further section of this paper. Apart from: Jezzyk arabski dla Polaków [Arabic for Poles] by Adnan Abbas and George Yacoub [2] and Podstawy języka arabskiego [The basics of Arabic] by Iwona Król and Adnan Hasan [3] - (a Polish publication whose character is purely textbook-like) The majority of the publications regarding this matter includes "self-study guides" based on the most rudimentary expressions used in conversation which are aimed at the beginner level students, although there are various levels of advancement available. This is reflected by the teaching methods used in the language courses where, quite often, the Arabic alphabet is not introduced due to the fact that its mastering requires a lot of time and effort. Hence, the above mentioned "self-study guides" are formed on the basis of juxtaposing three elements: an expression in Arabic written with the proper alphabet, followed by its representation written in the simplified transcription and the expression's counterpart in Polish (translation). The vast majority of the publications of this type promote the conversation and communication segment. They aim at presenting the most important expressions, allowing daily communication in the simplest, shortened and general way. Mostly, such publications are intended to make the tourists visit the countries of the Arab world. These "self-study guides" can be accompanied by Polish-Arabic phrase books [4].

There are also papers of didactic nature presenting the theoretical aspects of the curriculum for teaching Arabic [5]. Other publications which cover more specific subjects dedicated to the selected issues connected with the mastering of Arabic: lexis, [6], phraseology [7] or grammar [8]. It is worthy to emphasize here that the publishing office of Adam Mickiewicz University in Poznań has recently published a new book regarding the grammar on the threshold level [9]; this publication realizes the content of this stage of teaching Arabic in an interesting way.

Jezzyk arabski. Teksty $i$ ćwiczenia by Adnan and Amira Abbas is the textbook analyzed in this paper in the context of the cultural and realities studies. Second, amended, edition of the book was published by Adam Mickiewicz University publication office in 2006. As stated in the Introduction, the textbook is dedicated to the beginner students of Arabic studies and presents the fundamental subjects regarding grammar accompanied with various exercises, including the lexis which is gradually introduced in fifty-two lessons. The subjects are ordered in accordance to the gradation of the learners' advancement level. The authors of the book emphasize the fact that their publication is based on many years' experience gained during their work as the teachers of Arabic, presented in the form of a textbook to learn the language. They also stress the fact that it also covers cultural issues - the theme which is analyzed by the authors of this paper.

The textbook entitled Język arabski. Teksty i ćwiczenia presents the cultural issues referring to the numerous aspects of the daily life of the Arab community in various ways. As far as the technical aspects are concerned, sometimes the cultural content is introduced "through the back door" in the reading material included in each of the lessons, or entwined in the dialogues between the interlocutors. What is interesting, the interlocutors are always persons of various nationalities, i.e. the representative(s) of Polish and Arabic culture, however, the characters acting in the dialogues or in the subsequent chapters always have different names (there is no coherent series of stories featuring one or more recurring protagonists). In other cases, the cultural content is introduced in the form of exercises, for example "gap filling" ("......... is the capital city of Syria) or exercises, motivating the students to do their own research or increase the knowledge on various subjects regarding the Al-Watan $a l$ - 'Arabī, such as a request to formulate a few sentences about Iraq or to list the Arab countries of Africa. Some content is directly presented in the further sections of each lesson as a summary, or closing line in the form of a trivia as is the case with the quoted proverbs.

Having analyzed strictly linguistic elements regarding the cultural competence in the Abbas' textbook, one can conclude that the book contains mostly fundamental issues in this module. As early as in the first unit, the basic greeting forms used in the conversations (sabāḥu al-hayr, ilà al-liqà , etc.) are presented, while further pages contain other expressions of similar type, (for example $m a$ ' $a$ al-salāma) this practically exhausts the inventory of the expressions used on level A1-A2. However, body language accompanying these verbal gestures seems to be omitted and body language is particularly important in the light of the differences between the society of the west and the Arabic world. Other expressions used in the communication in Arabic are introduced in equally natural way: they are included in the dialogues which are held in restaurants or cafes. These include such expressions as: فضلك min

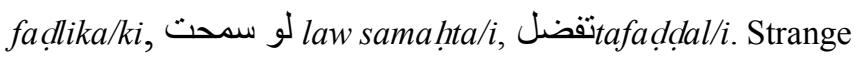
as it may seem, the expression كيف حالك؟ لو appears for the first time in lesson no. 9.

While discussing this issue, one should indicate an interesting measure taken in this textbook: by changing the names of the protagonists of the texts, each time a new one is introduced. This way the authors manage to present many Arabic names, expanding at the same time the cultural competence of the students. The textbook also contains the polite conventions of various types and shapes: apart from using the above mentioned expressions, also in the form of رحلة - expressing wishes (for example: have a good trip - rihla sa îda) or expressing grief or regret (for example, due to the fact that the protagonist has no time to pay a visit - زيارة-ziyāra). The authors of Jezzyk arabski... do not omit the exclamations expressing the awe and surprise, such as Mãahsana had̄ā! (ما أحسن هذا _ "It’s very beautiful!") and fixed phrases used in official and casual letters, telegrams and so on, with the examples of these types of texts. Also, other expressions for making the wishes on various 
occasions are presented here: (for example: كل عام و أنت بخير Kullu 'ām wa-anta/i bi-hiayr! or عيد مبارك 'Īd mubārak!), including the ones linked with the religion and used in numerous situations - farewell الله معك Allāh ma'ak; or blessing which is often used as a customary expression of: As-salāmu alaykum wa-rahmatu Allāh wa-barakātuhu. The discussed textbook also includes various fixed phrases and Arab proverbs, such as: بكل سرور bi-kull surür ("with pleasure"), وفي كالكلب wafí ka-al-kalb ("faithful as a dog"), Áfa al- ilm al-nisyān ("Oblivion does great damage to science").

Moving on to the analysis of the factual elements included in the scope of Arab culture present in the textbook written by Abbas, it should be noted that although the content of this type is indeed included in the book even to a large extent, it appears without regularity - some units do not contain cultural information at all, while the others contain the excess of such content. Język arabski. Teksty i ćwiczenia fails to realize all the assumptions of the curriculum for the cultural and realities studies in AFL on level A1-A2 presented in the previous paper, however, it does include the most important elements of the curriculum. Starting from the first pages we can see the examples of the Arabic calligraphy. Initially, they are presented in the form of pictures adorning the introductory texts to lesson units. Later on they appear as the presentation of the methods of writing down the given type of writing, its name and characteristic features, etc. Students using this type of textbook can become familiar with the characteristics of the particular styles of calligraphy, nash $\underline{i}$, tult $\underline{i}, k \bar{u} f \bar{i}$ and others. What is more, the textbook contains basic information regarding the Arab cuisine introduced in the dialogues held in a restaurant: such dishes as kebab (كباب kabāb), falafel (فلاب faläfil), baclava (بقلاوة) baqlāwa) are mentioned.

The issues connected with geography (al-ğuğgăfiyya) and history (at-târi $\underline{h})$ are the essential elements regarding the knowledge of the Arabic world. So, the names of the countries of Al-Watan al- 'Arabī, their capital cities and most important or best known cities are introduced in the form of exercises. In order to complete the tasks, students should be familiar with the political maps of the region (when they have to answer the question "Baghdad is the capital city of....") or geographical maps used in the exercises mentioning Euphrates (Nahr ad-Diğla), Tigris (Nahr al-Furāt) and their geographical locations; there are also questions regarding the location of the Arab states in the particular continents or the location of Palmyra (Tadmur). Abbas also introduce the issue of the political systems in some countries of Al-Watan al- Arabī. Additionally, while discussing the subject of tourist destinations, the authors mention important historically places which are of significant cultural meaning - for example, when Iraq is mentioned, the interlocutors briefly talk about $\operatorname{Ur}(\overline{U r})$, Basra (Al-Bașra), Mosul (Al-Mawsil) orBabylon (Bābil) with its legendary hanging gardens. When the protagonists plan the excursion to Cairo (Al-Qāhira), they discuss its monuments describing them briefly at the same time - Cairo Tower, 'Āmru Ibn al-'Āṣ Mosque, The Hanging Church, etc.. As far as the historical figures of the Arabic world are concerned, the textbook does not offer a wide scope of information. Ramesses (Ramsiss), the ruler of Egypt and a few renowned Arabs and Muslims, such as Ibn Sīna (Avicenna) or Al-Kindī are solely mentioned. Exercises accompanying the texts also require widened general knowledge of the countries of the Arabic region, and include the request to form few sentences about Iraq ( $A l$ - Irāqu) or the task of listing the most popular Arabic airlines, to name but a few.

Moreover, the religious elements are quite common in the discussed textbook - religion is mentioned while discussing the cities which are linked with this issue: Karbala (Karbalā $), \quad$ Najaf (An-Nağaf), Mecca (Makka al-Mukarrama). In order to complete some tasks successfully, students are required to have some information about the biography of Prophet Muhammad (Muhammad) such his birth place, the pillars of faith (arān $a d-d \bar{n})$, or fasting (sawm) in the month of Ramadan (ramadann). Particular units also include the questions regarding the hadith ( hadit), the meaning of The Quran (mentioned by the name used in the Arabic world, namely the Al-Qur'ān al-Karim - "The Noble Quran"), the Muslim calendar (at-taqwim al-hiğri) with the names of all the months. The authors are sure not to omit the Muslim (and Christian) holidays, indicating their nature, the Arabic names and the course of the festivities.

As far as the literature and other high and mass-culture platforms are concerned, Abbas have taken an interesting measure allowing the broadening of the knowledge regarding these matters: the units included in the further part of the textbook contain the excerpts of the best known poems of Arabic authors with their translation into Polish. One of the reading texts contains the fables taken from the classics of the Arabic literature - One thousand and one nights (Kitāb alf layla wa-layla). Another text presents an episode from the adventures of Sindbad the Sailor (As-Sindbād Al-Bahrî), fragments of the novel of Țâha Husayn or the poetry of Adonis. One of the chapters included in the final section of the book consists of the texts about the contemporary women writers of various regions of the Arabic world, for example about Liyāna Badr from Palestine, Sālima Șālih from Iraq, or Layla Al-'Utmān from Kuwait. Religious texts include fragments of certain surahs from the Quran, but also from the Gospel by St. Matthew in Arabic, accompanied by Polish translation. As far as the mass culture is concerned, the authors discuss various Arabic TV channels, with Qatar based Al-Ğazira in the first place.

More general issues linked with the Arabic customs mentioned by the authors of the textbook include "haggling" on a bazaar (Süq al-Hamídiyya) in Damascus, or discussing the wedding ceremony (az-zawāg) and the confrontation of a modern couple with their families' requests regarding the traditional form and appearance of the wedding. It is interesting that the authors also included a political theme presented on the occasion of the protagonists' discussion of 
parliamentary elections.

\section{French textbooks for teaching Arabic}

Contrary to Polish market, the array of the materials for teaching Arabic available on French publishing market is much wider. This fact results not only form the popularity of the Arabic in France, but also from the socio-political conditions - France is the home for many people of Arab origin, mostly from the countries of Maghreb (Al-Magrib). The vast majority includes a wide array of "self-study books" [10] and phrase books [11], similarly to the publications available in Poland. "Self-study books" which do not omit learning the alphabet and are more complex as far as the learning process of Arabic is concerned are also available. Additionally, there are a number of publications dedicated to teaching children [12] which are available in French market. Such books are virtually unavailable in Poland. The offer of French bookshops includes many works which are helpful in broadening the knowledge regarding the Arabic dialects [13] - such as Algerian or Moroccan (due to the presence of many representatives of Maghreb communities in France).

Apart from the types of publication dedicated to teaching and learning Arabic mentioned above, the market also offers academic textbooks designed for teaching Arabic as a foreign language in the form of the practical teaching or language classes offered by universities and language schools alike. Apart from the textbooks issued by academic publishing offices, one should mention two titles (similarly to the Polish edition, the analysis regards the registry of Modern Standard Arabic): Manuel d'arabe liitéral [14] and Manuel d'arabe moderne [15] which are included in the didactic material recommended for teaching AFL by the lecturers of Sorbonne.

In relation to the presence of the diglossive situation in France itself (due to large groups of native speakers of Arabic using the dialects from their homelands on the daily basis) some of the offered textbooks introduce the issues linked with the ESA (Educated Spoken Arabic, a variant of the Arabic which results from the interference of the Modern Standard Arabic registry with the dialects) instead of the MSA.

Manuel d'arabe littéral mentioned above is an interesting item as far as the cultural and realities elements are concerned, since this subject is clearly marked. Each unit is concluded with a note regarding the widely understood culture of the Arabic language area, describing, for example, sufism (at-tasawwuf) or the development of the Arabic (taqaddum al-luḡa al- 'arabiyya).

The textbook entitled Manuel d'arabe moderne was published in Paris in 2013 by the L'Asiateque publishing house as a new, expanded version of a textbook for beginners. In his publication, Luc-Willy Deheuvels included an extensive Introduction to its further, didactic part. It explains the layout and the objectives of Manuel d'arabe moderne characterizing and at the same time the construction of the book. However, in the first place, the Introduction describes the proposed teaching methods which - according to the author - differ from the usual ones. According to the author, the objective of the book is to introduce the university students to learning Arabic in its expanded form as quickly as possible. Additionally, the publication includes the essential minimum required to face modern text without assistance and also to recognize the various registries of the language. The textbook emphasizes the syntactic and morphology structure within the basic level, while the lexical pool is somewhat limited. Moreover, the book teaches the writing of the alphabet, while exercises in the form of the dialogues motivate the development of speaking skills. Referring to the cultural elements, the author ensures in the Introduction that what they must be included in the curriculum for Arabic is, first and foremost, the language of the culture. He justifies his claim with these words: "Learning Arabic does not only mean acquiring the communication skills but also discovering a fascinating reflection of rich and attractive world in the very heart of the language" (Deheuvels, 2013: 10).

Deheuvels' textbook undoubtedly realizes some assumptions of the cultural and realities studies curriculum whose outline was presented in the previous paper. However, it does so in a different form and in reference to issues which differ from the ones included in, for example, Język arabski. Teksty $i$ ćwiczenia by A. A. Abbas. As for the technical character of the presentation, the subjects regarding the customs of Al-Watan al- 'Arabī are usually presented in the reading matter placed at the beginning of each of 15 lesson units. However, they are also "hidden" in the example sentences explaining the grammar and the exercises accompanying the subsequent texts. One should also mention a specific role played by the footnotes included in the text - for example, whenever there is a reference to a historical figure, there is always a footnote containing biographical and general information regarding this figure. The textbook, however, does not feature the tasks which would encourage the students to undertake their own research on a given matter regarding the Arabic culture and the realities of the Arabic world, as opposed to the textbook written by the Abbas.

Moving on to the question of the elements regarding strictly linguistic skills, Deheuvels contained a vast knowledge on this matter in his publication, considering the fact that the material was developed with the basic level students in mind. The fact that - in spite of the dialogue-like forms used right from the first unit - the expression Ahlan! ("welcome") used for welcoming the visitors is only introduced in the third unit may be slightly different from the other textbooks. However, this expression appears in a natural form, as a part of a dialogue; similar situation applies to farewell expression represented by إلى اللقاء Ilà al-liqā’! ("See you"). It is worthy to mention the fact that apart from ahlan, and later on أهلا ("Peace be with you!"), the Manuel d'arabe moderne does not contain any other welcoming expressions, however, as far as farewell expressions are concerned, apart from the one 
listed above, one can only find مع السلامة Ma'a as-salāma! ("Good-bye"). The protagonists of the texts which are set in public locations (such as café, restaurant) do not forget to include the polite forms in their utterances - they use من فض min facllika/i ("please") and when they address other people they use the vocative case particle $y \bar{a}$ in conjunction with the name or title, for example يا شيخ yã šay used towards the elderly or the scholars) or يا سيدي yā sayyidi (literally: "oh, my master"; the official expression used as "Sir"). French textbook also teaches how to express the congratulations, although only one expression is used: مبرو Mabrük! (“congratulations!”). The final, strictly linguistic element present in the discussed textbook is the exclamations used by the protagonists. These include: Wa-Allāh! ("By God!") and the expressions of a religious character, such as: إن شاء الله In šảa Allāh ("If God wills.") i Li-wağhi Allāhi ("God will remunerate me"). An interesting addition to the expressions included in this scope, consists in introducing exclamation forms expressing the negative forms of communication: one of the dialogues contains the examples of verbal abuse in the form of: Yā aḥmaqu! ("you fool!") and أنت الحمار Anta al-ḥimāru! ("you oaf!").

The action of the reading matters is set in the Arabic realities which are widely understood by the author. The action takes place either in an Arab country or in a place which refers to such a country, as can be clearly seen through the names of the streets (for example: Baghdad Street). The author of the textbook managed to introduce a number of Arabic names which are listed together with their literal French translation into - among others, female name Nafisa translated as "Precious Stone" is introduced. All the protagonists are of Arab origin - in the first text we meet Karim who is Syrian. What is more, the protagonists with Arab names spend their leisure time in Al-Amir café ("Prince", "Emir") where - what is essential for presenting the daily culture - they drink tea ( $a \check{s} \check{s} \bar{s} \check{a} \bar{y})$, sometimes coffee (al-qahwa) and play backgammon (at-tâaila) or smoke water pipe ( $(\check{s} \check{s}-\check{s} \check{s} \check{s} a$ ) while discussing philosophy (al-falsafa). Another part of the textbook includes a character resembling an al-hakawāti, or story teller and people gather round to listen to his tale while drinking Arabic tea. On the other hand the book includes the customary matters referring to the mass culture and also the ones connected with tourism - such places as Cairo (Al-Qāhira), Beirut (Bayrü), or the Kurds' district of Al-Akrād in Damascus (Dimašq) are mentioned. There is also a fragment of the radio program about Fayrūz an icon of the Arab music, broadcasted by Radio Amman.

As far as the "high culture" is concerned, one of the first lesson units mentions the figure of a famous poet from the Abbaside Caliphate period (as per information in the footnote) - Abū Nuwās. Further, the author presents 'Amr Ibn Ma' dīkarib al-Zubaydī, a poet from the Jahiliyyah period with the legend of his conversion to Islam during the reign of caliph 'Umara (a reference to history). Other famous figures, such as the poet and the protagonist of the epic - 'Antara Ibn
Šaddād or Scheherezade, the key figure of the legendary One thousand and one night (Kitāb alf layla wa-layla) are also mentioned. The final, significant element linked with the "high culture" which can be found in Manuel d'arabe moderne is the adaptation of a short story from the collection of a Lebanese author Kāna mà kāna (Nu'ayma, 1937) which is based on the history of one of the beys, a dignitary from the Ottoman period (another reference to history).

History is another cultural element present in the French textbook. The author uses historical references linked with facts, events and figures. He mentions emir Faysal (Fayṣal.) the king of Iraq in $20^{\text {th }}$ century whose name was referred to when discussing the fight against Turks; Faruq (Farūq) the king of Egypt from the second half of $20^{\text {th }}$ century; Saladin (Ṣalāh ad-Dīna), the founder of the Ayyubid dynasty, sultan of Egypt and Syria; Avicenna (Ibn Sīnā) a doctor and philosopher; and the former leader of Egypt Gamal Abdel Nasser (Ğamāl 'Abd An-Nāsir), a known figure of modern history. The textbook also contains information regarding the Egyptian revolution, the battle of Al-Qandisiyya or the formation of the Arab League (Ğàm 'at ad-Duwal al- Arabiyya). This content is accompanied by an interesting socio-political motif, for example when the Arab League is mentioned, the problems of this organization are discussed. Also, it is easy to notice an element suggesting a reference to panarabism - when the guests of a radio programme talk about the book Le nationalisme arabe et nous (Arabic Nationalism and Us) there is a statement that the Arabs could be the driving force of the world provided that they are as united as during the umma. This regards the issue of the unification of the Al-Watan al- 'arabī, for - quoting one of the interlocutors - "Unity is the secret of the strength". Another example confirming the presence of the issues of social and political nature in the Manuel d'arabe moderne is one of the reading texts where the author indicates that each Egyptian village is ruled by two families holding the power and they are fighting for and each family supports a different political party.

The discussed textbook also includes the issues of geographical and natural sciences character: there is a map of the Arab world with the names of the countries and their capital cities. The texts of the subsequent lesson units include geographical elements exemplified in the form of questions such as: "Where is Rijâd??" accompanied by the correct reply. The other variants of the above questions regard other cities of Saudi Arabia: Jeddah ( $\breve{u} u d d a$ ), Mecca (Makka), Medina (Al-Madina).

Religion is the last cultural reference present in the Manuel d'arabe moderne. For the first time, the Quran $(A l-Q u r ' a n)$ is mentioned in the book when the role of the vocalization (at-taskill) in Arabic is discussed. Apart from that, there are few digressions linked with Islam (al-islām) and they include the reference to angel Gabriel ( Gibrïl), one of the characters goes to heaven after his death and meets Allah's messenger mentioned above and God himself. However, there are no references whatsoever to the subject of prayer (as-salāt), mosques (al-masāğgid) or Muslim 
customs (al- 'ādāt al-islāmiyya).

\section{Textbooks for learning Arabic in English}

American publishing market offers numerous publications enabling the initiation and continuation of learning Arabic, both in the shape of complex academic textbooks used at universities and language courses [16] and the typical "self-study guides" [17]. Phrase books that allow achieving the threshold language competence enabling the basic communication in the Arab countries are also readily available [18].

What is important, textbooks for learning AFL published all over the world are available in the US, although the vast majority of these publications consists in the locally published books or the ones published in the UK (one of the popular series is published by Cambridge University). Available textbooks are varied in terms of content and form; some of them allow mastering communicative Arabic in a short time. Many of the above mentioned books are written by specialists employed by the most renowned American and British universities such as Yale, Georgetown and Cambridge.

The authors of this paper analysed the textbook written by Mahdi Alosh, entitled Ahlan wa sahlan. The second edition of this book, designed for learning AFL at the basic level, was published by Yale University in 2010. It is full of Arabic culture present in various settings and forms including the text and multi-media (audio and audio-video). Such a construction of the textbook allows the presentation of culture and realities elements of the Al-Watan al- Arabī in a coherent, clear and complex way.

The author of the book included an elaborated Introduction where he states that the exercises were selected in such a way as to improve the communication by functional approach to the themes. Not only does he indicate an extended scope of grammar present in the publication, but also the lexical content and audio-visual material presenting the daily life of the Arab world (usually Syrian). The tasks developing receptive (reading and listening) and productive (speaking, writing) language skills are accompanied by exercises offering a wider look to the Arabic culture. Additionally, Alosh assures in the Introduction that his book contains the expressions used in daily communication, such as greetings, expressing gratitude, introductions, etc. which are introduced in a natural, real context. The author informs the reader that his texts refer to the culture of the Arabic world, but at the same time he emphasizes the fact that the phenomenon of the uniformity of the Arabic customs does not exist - it is rather a mixture of many cultures and customs. And so, Ahlan wa sahlan includes the issues regarding cuisine, dress code, customs, family, entertainment, geography, history or the famous characters associated with the region. Due to the omnipresence of the elements regarding the cultural competence in this publication, the authors decided to use more selective and more generalizing method of analyzing the discussed aspects.

As far as the technical side of Alosh's book is concerned, it has to be emphasized that the cultural and realities information is present in various forms here. Such elements appear in the reading texts, at times in a direct manner - some readings discuss strictly geographic or historical subjects, in other cases they have been hidden in the exercises. Primarily, however, the textbook features special, dedicated segments regarding the culture and the realities of the communities of native speakers of Arabic. Each lesson unit is complemented with photographs presenting various aspects and forms of the Arabic culture. In the Introduction the author states that he had used them as an encouragement for the learners to deepen their knowledge of these matters. Sometimes, the strictly cultural modules are accompanied by the pictures presenting the discussed issues in a pictorial form. Additionally, the included audio-video material is an important source of knowledge on the realities of the life of the Arabic community.

Starting from the matters included in the scope of strictly linguistic skills, Alosh, right from the first pages of his book, presents a wide range of the expressions which are used to greet (at-tahiyya)), say good-bye (at-tawdī ${ }^{\circ}$ ), express gratitude $(a \check{s}$-šukr) or requests (at-talab). Apart from the exemplary expressions such as صباح أخير Sabāh al-hayr! ("Good day!") or السلام عليكم As-salām alaykum! ("Peace be with you!") there are also questions regarding the well-being of the interlocutor, for example كيف حاللك Kayfa hâluka/i? ("How are you?") accompanied by the polite forms such as من فض min facllika/i ("Here you are"), تشرفا tašarrafnā ("I am pleased") and also لون سمحت law samahta/i ("If you can"). The characters often express their regret using the expression آسف asif ("I am sorry") and also use the vocative particle $ا$ y yā. Also, religious expressions are presented in the book: إن شاء الهاء In šă'a Allāh ("If the God wills.") or اله أعلم Allāh a lam ("the Only God knows."). An important element of Ahlan wa sahlan regarding the linguistic matters is the usage and the explanation of the context of the expressions used to address someone: سيدي sayyidī ("Sir...”), أخي ahī ("brother"), etc. This matter also appears in relation to the expressions used in writing, for example عزيز 'aziz ("dear..."). The author also explains the phenomenon of using the expression حبيبي habỉbi ("beloved"). What is more, the characters of the discussed textbook know how to congratulate their interlocutors and they express wishes for them using, for example, كل سنة Kull sana wa-anta sālim! (“All the best!”).

Almost each lesson unit in Ahlan wa sahlan contains the elements of the knowledge of the Arab culture. They do not always appear regularly and in the same proportions in all units. However, the author always emphasizes this aspect. First of all, each chapter features a photograph presenting a fragment of the reality of Al-Watan al- 'Arabī. Once, it is a photograph of a souvenir shop, on another occasion a photo of a man selling the liquorice drink on a bazaar. The characters appearing in the texts have Arabic names and 
often study in the Arabic countries (or are Arabs visiting the USA), for example Hāla Bustānī, born in Damascus and studying at the university in Aleppo. One of the special modules dedicated to culture features the matter of the Arabic surnames and their origin, the meanings of some names are also provided.

The varied realities of the given countries of the region are also presented in the reading texts: in one of them, the student meets Lu'lu'a who, being a citizen of Qatar, owns a large house in Doha, a few cars and a chauffeur - this reflects the reality of one of the wealthiest states in the world - Qatar. Nevertheless, considering the book as a whole, the characters of Ahlan wa sahlan originate from various social classes and live in varied conditions. By the way, the book also mentions the role of the family in the Arabic society, the essence of having children and the condition of women. Alosh also included the Muslim dress code - he briefly describes the women's attire (with the picture presenting hijab), but there is also a description of men's clothes, with the names of the gowns mentioned in the text (such as ghutra or keffiyeh) and their photographs. What is more, the learners get to know the ways of spending free time in Arabic countries - he talks about sports and the popularity of football, family meetings with tea, watching the Arabic TV, etc. The protagonists of the reading texts read Arabic newspapers and magazines. One of the readings is fully dedicated to the Arabic press and many titles are mentioned (such as the Egyptian الأهرام Al-Ahrām, Saudi الشرق الأوسط A Ǎšrarq Al-Awsat, Tunisian Al-Fikra). They try the specialities of the Arabic cuisine, thus the learner is exposed to فعية فلافل faläfil, ta 'miyya, حمص himmas, and he can read the menu from a restaurant located in the region of Al-Watan al-Arabi. Students learning Arabic from the discussed textbook can read about visiting Cairo (Al-Qāhira) or Alexandria (Al-Iskandariyya) - they look at the Pyramids, ride the camels, visit the National Museum of Cairo or Muhammad 'Ali mosque. Another cultural element present in Ahlan wa sahlan is the popular music - the author mentions Umm Kultum, Fayrūz, 'Abd Al-Halīm Hāfiz, and also contemporary singers such as Nānsī 'Ağram. One of the reading texts includes the list of the Arabic TV channels. At this point it is worthy to emphasize the role played by the audio-video material allowing the learner to watch the protagonists of the book playing the Arabic games, drinking tea, sitting in a cafe reading newspapers published in Al-Watan al- 'Arabī - this way of characterizing the Arabic culture and the daily realities of the native speakers of Arabic is quite intensive and easy to perceive.

As far as the factual knowledge is concerned, the texts in Ahlan wa sahlan contain numerous historical (at-tarīh) and geographical (al-ğuğgāfiyya) references. The author presents Damascus, Cairo and Tunis; he also introduces the names of Arabic countries and cities (which often differ from their European counterparts, for example Al-Quds, or Jerusalem). Some exercises also motivate students to deepen their knowledge within this scope, for example with questions such as "List the Arabic cities you know". The book also touches upon the matter regarding the Persian Gulf and the problem with the nomenclature (Persian Gulf versus Arab Gulf), there is also a separate text dedicated exclusively to the geography of the Al-Watan al-Arabĩ: location, the neighbouring countries and regions, division into its regions

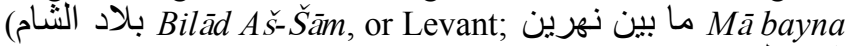
Nahrayn - Mesopotamia, contemporary Iraq; شبه الجزيرة Šibh al-Ğazira al- Arabiyya - Arabian Peninsula; شَّimāl Ifrīqiyā - Northern Africa). More detailed descriptions include Syria (Süriyya) and the river Nile (Nahr an-Nïl) - the author provides detailed information regarding the countries and places located over the river, its origin and estuary. As far as the historical elements are concerned, they are not as strongly represented as the geographical ones. The author mostly mentions the figures of famous characters and their achievements, for example Ibn Chaldun (Ibn Haldūn), Abdel Kader ("Abd al-Qādir), Gamal Abdel Nasser (Ğamāl 'Abd an-Nāṣir). These elements are present when discussing, for instance, the Independence Day both in the USA and in the Arabic countries (there is a table listing the dates of this holiday in each of the countries). In this section of the book dedicated to the beginner learners - these are the only historical themes.

Religion is the final cultural element included in Ahlan wa sahlan. Apart from the reference to the dress code, the author mentions the Muslim calendar (at-taqwim al-hiğrî) - he presents its scheme and the names of the months. Additionally, the author describes the date and methods of celebrating the most important festivals of Islam: Eid al-Fitr (festival of breaking the fast, 'Id al-Fitr)) which occurs after the fasting month of ramadān and Eid al-Adha (festival of sacrifice, 'Id al-Ac̣hà), celebrated in the month of $\underline{d} \bar{u}$ al-hịğğa.

\section{Summary}

On the basis of the performed analysis, one can conclude that the discussed publications realize the assumptions of the culture and realities studies designed to be introduced in correlation with the practical teaching of AFL in a different way and to various extents. Even though each of the discussed textbooks includes larger or smaller component linked with the customs and realities of the Arabic world and the native speakers of Arabic, it seems that the book written by Mahdi Alosh, Ahlan wa sahlan develops these matters in the most comprehensive way. Hence, it allows the best development of the cultural competence of the learner. This textbook includes all the elements of the knowledge regarding the Arabic language area [19]: daily life (food and drinks, meal times, table manners, leisure time and leisure activities, work, organization of the work, learning); living conditions (living standards, flats and houses, healthcare, social care); human relationships (class structure, relations between various social classes, sexes, generations and ethnic groups, family, workplace and school relations); systems of 
values, political views, attitudes (customs versus social changes, minorities, national identity, art, religion, humour, politics); body language; social conventions (being on time, giving presents, dress code, taboos, conventional rules of behaviour and conversational rules); ritual activities (festivities, holidays, public events, etc).

This type of knowledge is essential for shaping the (inter)cultural competence. The cultural competence, undoubtedly, constitutes a significant complementation of the linguistic education goals. Its development favours the fuller realization of the key objective of this type of education, namely, achieving the communication competence. This is reflected in more and more commonly used term of the "intercultural communication competence". The intercultural communication competence consists of four elements: linguistic competence; socio-linguistic competence; discourse competence and intercultural competence. The first of these aspects is the knowledge included in the range of the language code: phonetics, lexis, syntax, morphology and semantics. Socio-linguistic competence in turn is based on the correct usage of language depending on the profile of the recipient and contextual conditions. Discourse competence deals with correct organization of the text. The last of these aspects, intercultural competence is the most complex, as it can be broken down into three sub-aspects. The first of them is knowledge: familiarity with the products and norms characteristic for one's own culture and the interlocutor's culture as well as general processes of social and individual interaction. The second is skills: the skill of interpreting and making reference to the content included in the communication activity within the frame of another culture, the ability to explain it and relate it to the events characterizing one's own culture; the ability to discover the unknown and to interact assuming the ability to absorb and use the knowledge on culture. The usage of the knowledge (accompanied by skills and attitude) must be adapted to the limits imposed by the daily communication and interaction and it must be supported by unbiased evaluation on the basis of clearly defined criteria of thought, customs and characteristic products of one's native and foreign culture. The last sub-aspect of the intercultural competence is the attitude: curiosity of the world, sensitivity and being open towards different culture, refraining from the prejudices and the conviction of the supreme efficiency of one's own patterns of behaviour.

At the same time one must not forget that "learning foreign languages is getting to know foreign cultures, while getting to know other cultures is inseparably linked with learning languages" [20]. Also, one should emphasize that the basic element in the development of intercultural competence is a mindful relation to one's own language, culture, society, systems of norms and values or, to put it in simple words - native cultural patterns constituting the basis and foundation of our identity and exerting a great influence on the process of learning a foreign language and the culture it represents. Therefore, the starting point should consist in developing a skill of making reference to the matters that are linked with the learner's native cultural circle by realizing that the perception is culturally conditioned. Then, it is time for the development of the skill of mediation between the foreign and native culture by becoming aware that there are some differences and similarities present. The above are accompanied by the ability to identify and solve the problems and misunderstandings of cultural nature and finally - the emphatic skills expressed by the readiness to include the variety of expressions, norms and patterns of behaviour resulting from the affiliation with different cultural circles in the communication process.

\section{REFERENCES}

[1] A. Abbas, A. Abbas. Język arabski. Teksty i ćwiczenia, Wydawnictwo UAM, Poznań, 2006.

[2] A. Abbas, G. Yacoub. Język arabski dla Polaków. Podręcznik dla początkujących, Wiedza Powszechna, Warszawa, 2010.

[3] I. Król, A. Hasan. Podstawy języka arabskiego, Wydawnictwo Akademickie Dialog, Warszawa 2012.

[4] D. Samek. Rozmówki polsko-arabskie, Wydawnictwo Rea, Warszawa, 2004; Arabski. Kurs podstawowy. Edgard, Warszawa, 2008; Arabski. Krok dalej. Edgard, Warszawa 2011; Arabski nie gryzie!. Edgard, Warszawa, 2012; Arabski. Podstawy konwersacji, Wydawnictwo Rea, Warszawa, 2013; U. Michalska. Rozmówki polsko-arabskie, Wydawnictwo Kram, Warszawa, 2014.

[5] E. Górska, M. Skoczek, A. Hassan. Dydaktyka języka arabskiego, Wydawnictwo Akademickie Dialog, Warszawa, 1999; I. Król. Nauczanie języka arabskiego, Wydawnictwo UJ, Krakóa), 2005; M. Lewicka, B. Michalak-Pikulska (ed.). Dydaktyka języka arabskiego. Teoria - praktyka perspektywy, Wydawnictwo Naukowe UMK, Toruń, 2013; M. Lewicka, B. Michalak-Pikulska (ed.). Dydaktyka języka arabskiego. Rozwijanie receptywnych sprawności językowych, Wydawnictwo Naukowe UMK, Toruń, 2014; M. Lewicka, B. Michalak-Pikulska (ed.). Dydaktyka języka arabskiego. Rozwijanie produktywnych sprawności językowych, Wydawnictwo Naukowe UMK, Toruń, 2015.

[6] I. Król, A. Hasan. Słownik tematyczny języka arabskiego, Wydawnictwo Akademickie Dialog, Warszawa, 2007; M. Lewicka. Arabski słownik tematyczny, Wydawnictwo Kram, Warszawa, 2016.

[7] J. Kozłowska, G. Yacoub. Ćwiczenia z arabskiej frazeologii, Wydawnictwo Akademickie Dialog, Warszawa, 2000.

[8] J. Kozłowska. Gramatyka języka arabskiego. Ćwiczenia, Wydawnictwo Akademickie Dialog, Warszawa, 2009.

[9] H. Jankowski, P. Muchowski (ed.). Język arabski - ćwiczenia gramatyczne. Poziom początkujący, Wydawnictwo UAM, Poznań, 2015.

[10] C. Canamas, M. Neyreneuf, M. Bakri. Arabe pratique de base, Lgf, Paris, 2002; B. Hallaq. 40 leçons pour parler arabe, Pocket, Paris, 2009; R. Belmouhoub. Lire et écrire l'arabe, Larousse, Paris, 2010; H. Hadjadji, H. Kadra-Hadjadji. Méthode d'arabe moderne, Bachari Eds., Paris, 2012; C. Sakr. 
Al-Alif: premiers pas en arabe, Ellipses Marketing, Paris, 2013; A. Bouchentouf. L'arabe pour les nuls, First, Paris, 2015.

[11] L. Basili, N. Bellamine, C. Bourbon, N. Mondequer. Guide de conversation arabe du Proche-Orient, Larousse, Paris, 2007; J. Smart, F. Altorfer. Arabe, méthode intégrale: pour débutants et faux-débutants, Harrap's, Paris, 2012; L'arabe dans votre poche, Larousse, Paris, 2013.

[12] Q. Saadi, S. Husar. Chante et découvre l'arabe, ABC Melody, Paris, 2008; G. Vervelle-Bethelet. Mon premier imagier français-arabe, Mille Pages Eds., Paris, 2013; M. Abella-Keftouna. J'apprends à lire et écrire l'arabe, Al Bouraq, Paris, 2014.

[13] M. Djebli. Méthode d'arabe maghrébin moderne, L'Harmattan, Paris, 1988; N. Tapiero. Manuel d'arabe algérien moderne, Klincksieck, Paris, 2008; W. Ben Alaya. L'arabe tunisien de poche, Assimil, Chennevières-sur-Marne, 2010; H.-G. Samsek. L'arabe égyptien de poche, Assimil, Chennevières-sur-Marne, 2011.

[14] N. Khalfalllah, L. Denooz. Manuel d'arabe littéral, Studyrama, Paris, 2014.

[15] L.-W. Deheuvels. Manuel d'arabe moderne, L'Asiateque, Paris, 2013.

[16] J. Wightwick, M. Gaafar. Arabic verbs and essentials of grammar: a practical guide to the mastery of Arabic,
Mc-Graw Hill, Lincolnwood, 1998; E. Schulz, G. Krahl, W. Reuschel. Standard Arabic: An Elementary-Intermediate Course, Cambridge University Press, Cambridge, 2000; J. Wightwick. Mastering Arabic, Hippocrene Books, New York, 2008; M. Alosh. Ahlan wa Sahlan, Yale University Press, New Haven, 2011; B.K. Frangieh. Arabic for Life, Yale University Press, New Haven, 2011; K.C. Ryding. Arabic: A Linguistic Introduction, Cambridge University Press, Cambridge, 2014.

[17] K.K. Kershul. Arabic in 10 minutes a day, Bilingual Books, Seattle, 2007; F. Mansouri, Y. Alreemawi. Instant Arabic: How to Express 1,000 Different Ideas with Just 100 Key Words and Phrases!, Tuttle Publishing, Singapur, 2007; K. Brustad, M. Al-Batal, A. Al-Tonsi. Al-Kitaab fii Ta'allum al-'Arabiyya, Georgetown University Press, Georgetown, 2011.

[18] F. Mansouri, Y. Alreemawi. Survival Arabic, Tuttle Publishing, Singapur, 2008; F. Mansouri. Essential Arabic: Speak Arabic with Confidence!, Tuttle Publishing, Singapur, 2012.

[19] Council of Europe. Europejski system opisu kształcenia językowego: uczenie się, nauczanie, ocenianie, Wydawnictwa CODN, Warszawa, 2003, 95-96.

[20] M. Torenc. Nauczanie międzykulturowe - implikacje glottodydaktyczne, Oficyna Wydawnicza ATUT, Wrocław, 2007, 9 . 